\title{
ANTIOXIDANT ACTIVITY AND CONCENTRATION OF SECONDARY METABOLITES IN THE PLANT PARTS OF Euphorbia cyparissias L.
}

\author{
Milan S. Stanković and Nenad M. Zlatić \\ Department of Biology and Ecology, Faculty of Science, University of Kragujevac, \\ Radoja Domanovića 12, 34000 Kragujevac, Republic of Serbia \\ E-mail: mstankovic@kg.ac.rs
}

(Received April 1, 2014)

\begin{abstract}
This paper presents the results of a screening of nine different extracts from the plant parts (leaves, flowers and stems) of Euphorbia cyparissias for total phenolic content, concentration of flavonoids and in vitro antioxidant activity. Main reason for this study is the determination of these parameters and their variability among plant parts and plant extracts obtained by different solvents, respectively. Obtained amounts for total phenolic content ranged from 10.76 to $40.72 \mathrm{mg} \mathrm{GA} / \mathrm{g}$. The concentration of flavonoids varied from 34.32 to $134.34 \mathrm{mg} \mathrm{Ru} / \mathrm{g}$. The $\mathrm{IC}_{50}$ values of antioxidant activity varied from 88.48 to $2891.08 \mu \mathrm{g} / \mathrm{ml}$. Results obtained from the different plant parts were of uneven value. Great variability of the studied parameters was observed when comparing the effectiveness of the used solvents. The acetone extracts from stems contain the greatest concentrations of phenolic compounds, especially flavonoids, and showed high antioxidant activity. According to our research, plant parts from E. cyparissias can be regarded as promising candidates for natural plant sources with high value of biological compounds.
\end{abstract}

Key words: Euphorbia cyparissias, phenolic compounds, flavonoids, natural antioxidants

\section{INTRODUCTION}

Genus Euphorbia is the most multitudinous genera of family Euphorbiaceae, comprised of about 2.000 species. There are certain widespread species whereas some others are endemic, having different life forms such as annual or perennial, herbaceous, woody or bushy, hygrophytes, mesophytes or succulent xerophytes (THAKUR and PATIL, 2011).

Species of this genus are important in many aspects. On one hand, some are well-known for their usage in traditional medicine or for decorative purposes, but on the other hand some represent the source of toxical substances for the reason of producing secondary metabolites of different chemical structure and effects on man and animals. In folk medicine in different parts of the world some species of the genus Euphorbia are used for the treatment of dermatological diseases, parasitic diseases of the digestive tract as well as for the stimulation of wound healing (OzBILgin and Saltan Citoglu, 2012). One specific characteristic of the species of the genus Euphorbia is milky sap or latex, usually leaking from latex vessels upon damaging the plant, which is, as well as leaves and flowers, generally approved as curative in the folk medicine.

The most common secondary metabolites determined in the above-ground parts and in the the latex of Euphorbia species are diterpenoids, triterpenoids, sesquiterpenoids, flavonoids, phenolic acids and others (Wu et al., 2009; AYATOLLAHI et al., 2009; QAISAR et al., 2012). Upon testing of biological activity of E. cyparissias secondary metabolites, there were 
determined antimicrobial, (UPADHYAY et al., 2010; KIRBAG et al., 2013), antiviral (SALMASI et $a l .$, 2011), antioxidant (ASLANTURK and ASKIN CELIK, 2012), anticancer (SADEGHI-ALIABADI $e t$ $a l .$, 2009; LANTOVOLOLONA et al., 2013), anti-inflammatory and certain therapeutic activities (BARLA et al., 2006).

Species of the genus Euphorbia are not equally explored in terms of the characteristics and activities of secondary metabolites. Species which were the subject of the research are mainly species used in the traditional medicine: E. virgata, E. myrsinite, E. falcata, E. platyphyllos, E. microsciadia, E. peplus, E. pekinensis, E. hirta, E. macroclada.

Cypress spurge, Euphorbia cyparissias L. is a widespread species in the territory of Europe. This is a perennial herbaceous plant about $15-30 \mathrm{~cm}$ high up to $50 \mathrm{~cm}$ tall. The leaves are linear, spirally arranged on the stem, up to $4 \mathrm{~cm}$ long and $1 \mathrm{~mm}$ wide. The blossoms are finely set in yellow color and a very specific structure. This species occurs in habitats with a wide range of altitude and water regime.

Among the numerous medicinal plants generally used in both traditional and modern therapy, a certain number of species contains toxic active substances which restrict their usage to severely controlled doses (BOTHA and PENRITH., 2008). Many of these plant species are indispensable in medical tretments of various health problems due to the both medicinal and toxic nature of substances in them. In general, the usage of these plants is based on two principles: previously chemical purification or strictly controlled dosing (CRISTINA et al., 2013; CRISTINA et al., 2014). It is important to mention that most of these substances in small quantities have a therapeutic effect, while in excessive amounts or in the wrong applications exhibit toxicity (MCGAw and ElofF, 2005). For example, Taxus baccata, Colchicum autumnale, Digitalis purpurea and the other, as well as the some species from the genus Euphorbia, are important sources of medicinal substances with a standardized using, but they are also on the list of toxic plants (BERNHOFT, 2010). The Euphorbia species contain both toxic diterpenes in latex substance and seeds which induce skin irritation upon closer contact with skin, or vomiting when taken in (HSUEH et al., 2004; KARIMI et al., 2009) and secondary metabolites with biological and therapeutic significance (QAISAR et al., 2012), such as anticancer, antibacterial, antiviral, antiparasitic and other medicinal activity (MWINE and VAN DAMME, 2011; ÖZBILGIN and ÇITOĞLU, 2012).

The present study is prompted by the facts that no data on total phenol content, flavonoid concentration and antioxidant activity of E. cyparissias have been provided so far, and that, in the literature, there are no data concerning the comparative analysis of these characteristics of the different plant parts. Taking into consideration the fact that researches carried out by now showed that secondary metabolites of this species are the source of anticancer, antiviral, antiparasitic and insecticidal and molluscan activity (CRISTINA et al., 2008; SEMNANI et al., 2013), and that E. cyparissias is on the list of Serbian pharmacognosy flora (RANĐELOVIĆ et al, 2002) with applications (VUKOSAVLJEVIĆ et al., 2009), as well as studies conducted on the basis of its application in accordance with the possible toxicity (CRISTINA et al., 2013; CRISTINA et al., 2014), the main goal of the presented study was to define the contents of total phenolics and concentrations of flavonoids as well as to examine the antioxidant activity of E. cyparissias extracts obtained from leaves, flowers and stems using methanol, acetone and ethyl acetate. This examination was conducted in order to complete the data on this species putting special emphasis on the correlation between the quantity and antioxidant activity as well as on the other already proved significant biological effects of secondary metabolites as sources of biological activity.

\section{MATERIAL AND METHODS}

\section{Chemicals}

Acetone, methanol, ethyl acetate and sodium hydrogen carbonate $\left(\mathrm{NaHCO}_{3}\right)$ were purchased from "Zorka pharma“ Šabac, Serbia. The Folin-Ciocalteu's reagent, aluminium 
chloride hexahydrate $\left(\mathrm{AlCl}_{3}\right)$ were from Fluka Chemie AG, Buchs, Switzerland. Standards of phenolic acids (gallic acid) and of flavonoids (rutin hydrate), 2,2-dyphenyl-1-picrylhydrazyl (DPPH) were obtained from Sigma Chemicals Co., St Louis, MO, USA. All other solvents and chemicals were of analytical grade.

\section{Plant material}

Euphorbia cyparissias was gathered in April 2011, from the borough Ivanjica in western Serbia: (position: 43 $33^{\circ} 17^{\prime \prime} \mathrm{N}, 20^{\circ} 9^{\prime} 45^{\prime \prime} \mathrm{E}$, altitude $448 \mathrm{~m}$, exposition: W, habitat: meadow). The voucher specimen of E. cyparissias L., April 19 ${ }^{\text {th }}$ 2011., det.: Nenad Zlatić; rev.: Milan Stanković, were confirmed and deposited at in Herbarium at the Department of Biology and Ecology, Faculty of Science, University of Kragujevac. Collected herb was air-dried at dark place and ambient temperature $\left(20^{\circ} \mathrm{C}\right)$. The dried herb was cut up and stored in sealed containers until the use.

\section{Preparation of plant extracts}

The air-dried herb marerial (10 g) was broken in small pieces, 2-6 $\mathrm{mm}$ with usage of cylindrical crusher and extracted with different solvents (methanol, aceton, ethyl acetate), using Soxhlet apparatus. The extract was refined trough a filter paper (Whatman, No.1) and evaporized.

\section{Determination of total phenolics in the plant extracts}

The total phenolics concentration was determinated using spectrophotometre (SINGLETON et al., 1999). Used concentration of methanol solution of the extract was $1 \mathrm{mg} / \mathrm{ml}$. For preparation of reaction mixture it was mixed $0.5 \mathrm{ml}$ of methanol solution of the plant extract, 2 $\mathrm{ml}$ of $7.5 \% \mathrm{NaHCO}_{3}$ and $2.5 \mathrm{ml}$ of $10 \%$ Folin-Ciocalteu reagent dissolved in water. The blank was prepared containing $0.5 \mathrm{ml}$ of methanol, $10 \%$ Folin-Ciocalteu reagent dissolved in water and $2 \mathrm{ml}$ of $7.5 \%$ of $\mathrm{NaHCO}_{3}$. Test tubes are incubated at $45{ }^{\circ} \mathrm{C}$ for $45 \mathrm{~min}$. Spectrophotometre, at wave length of $\lambda$ max $=765 \mathrm{~nm}$ is used to measure the absorbance. The test samples were prepared in triplicate for each analysis and the mean value of absorbance was obtained. The similar process was repeated for the standard solution of gallic acid and the calibration line was constructed. Based upon absorbance which is measured, the total concentration of phenolics was read $(\mathrm{mg} / \mathrm{ml})$ from the calibration line; then the content of phenolics in extracts was marked in terms of gallic acid equivalent ( $\mathrm{mg}$ of $\mathrm{GA} / \mathrm{g}$ of extract).

\section{Determination of total flavonoids in the plant extracts}

The total index of flavonoids in the tested herb extracts was determinated using spectrophotometre (QUETTIER et al., 2000). The test sample contained $1 \mathrm{ml}$ of methanol solution of the extract in concentration of $1 \mathrm{mg} / \mathrm{ml}$ and $1 \mathrm{ml}$ of $2 \% \mathrm{AlCl}_{3}$ solution dissolved in methanol. The test samples were incubated for an hour at ambient temperature $\left(20{ }^{\circ} \mathrm{C}\right)$. The absorbance was measured using spectrophotometer at wave length of $\lambda_{\max }=415 \mathrm{~nm}$. The test samples were prepared in triplicate for each analysis and the mean value of absorbance was obtained. The similar process was repeated for the standard solution of gallic acid and the calibration line was constructed. Based upon absorbance which is measured, the total concentration of flavonoids was read $(\mathrm{mg} / \mathrm{ml})$ from the calibration line; then the content of flavonoids in extracts was marked in terms of routine equivalent (mg of RU/g of extract).

\section{Evaluation of antioxidant activity}

The efficiency of the plant extract to expurgate 1,1-dyphenyl-2- picrylhydrazyl (DPPH) free radicals was defined by the standard process (TEKAO et al., 1994), accepted with adequate modifications (KUMARASAMY et al., 2007). DPPH was dissolved in methanol to obtain a concentration of $80 \mu \mathrm{g} / \mathrm{ml}$. The solution of plant extract was prepared in methanol to achieve the concentration of $1 \mathrm{mg} / \mathrm{ml}$. Dilutions were made to obtain concentrations of 500, 250, 125, 62.5, $31.25,15.62,7.81,3.90,1.99,0.97 \mu \mathrm{g} / \mathrm{ml}$. Diluted solutions (1.00 ml each) were compounded with DPPH $(1 \mathrm{ml})$. After half an hour in dark place and ambient temperature $\left(20{ }^{\circ} \mathrm{C}\right)$, the absorbance was registered at $517 \mathrm{~nm}$. Inhibition was calculated in percentage using Eq. (1), as 
follows $\mathrm{IC}_{50}$ values were estimated from the $\%$ inhibition versus concentration plot, using a nonlinear regression algorithm. The data were introduced as midvalue \pm standard variation $(n=3)$.

$$
\% \text { inhibition }=\left(\frac{A \text { of control }-A \text { of sample }}{A \text { of control }}\right) \times 100
$$

\section{Statistical analysis}

Experimental measurements were managed out in triplicate and are expressed as arithmetical mean of three analyses \pm standard deviation. Statistical analysis was done using a SPSS (Chicago, IL) statistical software package (SPSS for Windows, ver. XII, 2008).

\section{RESULTS AND DISSCUSION}

The examination of the total phenol content, concentrations of flavonoids and antioxidant activity was conducted using 9 plant parts extracts which were prepared using methanol, acetone and ethyl acetate as effective solvents with different polarity. Various solvents are used to achieve the extraction of active substances with diversity in their polarity.

Examined contents of phenols in plant extracts obtained using Folin-Ciocalteu reagent was expressed in terms of gallic acid equivalent, GAE. Content of total phenols is represented in Table 1.

Table 1. Total phenol contents in the plant extracts of E. cyparissias expressed in terms of gallic acid equivalent, GAE (mg of GA/g of extract).

\begin{tabular}{lccc}
\hline \multicolumn{1}{c}{ Type of extract } & Methanolic & Acetone & Ethyl acetate \\
\hline Leaves & $20.29 \pm 0.24$ & $23.71 \pm 0.83$ & $20.82 \pm 0.47$ \\
Flowers & $17.97 \pm 0.30$ & $22.20 \pm 0.73$ & $10.76 \pm 0.95$ \\
Stems & $33.50 \pm 0.53$ & $40.72 \pm 0.92$ & $34.07 \pm 1.07$ \\
\hline
\end{tabular}

Each value in the table was obtained by calculating the average of three analyses \pm standard deviation.

Obtained concentrations of total phenols ranged from 10.76 to $40.72 \mathrm{mg} \mathrm{GA} / \mathrm{g}$. The acetone stem extract had the highest concentration of phenols ( $40.72 \mathrm{mg} \mathrm{GA} / \mathrm{g})$, followed by ethyl acetate extract $(34.07 \mathrm{mg} \mathrm{GA} / \mathrm{g}$ ) and methanolic extract of stem $(33.50 \mathrm{mg} \mathrm{GA} / \mathrm{g})$.When comparing the effectiveness of the used solvents, it was noticed that acetone has been a very effective solvent in the process od extraction of all plant parts used in the research. Of all tested plant parts, the stem contains the highest amount of total phenolic compounds in the extracts obtained using all three solvents. All results of the thorough analysis of the E. cyparissias show that different parts of the plant contain different amount of total phenolic compounds.

The concentration of flavonoids in various extracts of $E$. cyparissias is determined using spectrophotometric method with $\mathrm{AlCl}_{3}$. The content of flavonoids is expressed in terms of rutin equivalent, $\mathrm{RuE}, \mathrm{mg}$ of $\mathrm{Ru} / \mathrm{g}$ of extract. The summary of quantities of flavonoids identified in the tested extracts is shown in Table 2.

Obtained concentration of flavonoids ranged from 34.32 to $134.34 \mathrm{mg} \mathrm{Ru} / \mathrm{g}$. The acetone extract from leaves had the highest concentration of flavonoids $(134.34 \mathrm{mg} \mathrm{Ru} / \mathrm{g})$, followed by ethyl acetate extract from leaves $(107.12 \mathrm{mg} \mathrm{Ru} / \mathrm{g})$. The effectiveness of the used solvents varies in comparison to different plant parts. From the obtained results we infer that the acetone proved effective when it comes to the extracts of both leaves and tree, whereas the methanol was found as the most adequate solvent of the extracts of flowers. On the broader plan, it is vital to interpret the Table 2 which exemplifies the comparison of the amount of flavonoid compounds obtained using different solvents in several plant parts. Namely, leaves with the highest concentration of 
flavonoids are among the acetone and ethyl acetone extracts while the flowers are among methanole extracts.

Table 2. Flavonoid contents in different plant extracts of E. cyparissias expressed in terms of rutin equivalent (mg of RU/g of extract).

\begin{tabular}{lccc}
\hline \multicolumn{1}{c}{ Type of extract } & Methanolic & Acetone & Ethyl acetate \\
\hline Leaves & $77.83 \pm 0.39$ & $134.34 \pm 0.52$ & $107.12 \pm 0.77$ \\
Flowers & $79.12 \pm 0.92$ & $57.91 \pm 0.68$ & $46.09 \pm 0.77$ \\
Stems & $59.41 \pm 0.81$ & $69.39 \pm 0.75$ & $34.32 \pm 0.99$ \\
\hline
\end{tabular}

Each value in the table was obtained by calculating the average of three analyses \pm standard deviation.

The antioxidant activity of plant parts extracts from E. cyparissias was determined using methanol solution of DPPH reagent. Method is based on the reduction of methanolic solution of colored DPPH free radical by free radical scavengers from plant extracts. The scavenging activity was measured as the decrease in absorbance of the samples versus DPPH standard solution (BRAND-WILLIAMS et al., 1995). The antioxidant activity is expressed in terms of $\mathrm{IC}_{50}$ $(\mu \mathrm{g} / \mathrm{ml})$ values (Table 3$)$.

Table 3. DPPH scavenging activity of investigated plant extracts presented as percentage of neutralization and $\mathrm{IC}_{50}$ values $(\mu \mathrm{g} / \mathrm{ml})$.

\begin{tabular}{lccc}
\hline \multicolumn{1}{c}{ Type of extract } & Methanolic & Acetone & Ethyl acetate \\
\hline Leaves & $193.22 \pm 1.78$ & $514.00 \pm 1.89$ & $805.30 . \pm 0.89$ \\
Flowers & $197.85 \pm 0.96$ & $1985.14 . \pm 1.48$ & $2891.08 \pm 1.96$ \\
Stems & $88.48 \pm 0.53$ & $95.76 \pm 0.75$ & $158.16 \pm 1.12$ \\
\hline
\end{tabular}

Each value in the table was obtained by calculating the average of three analyses \pm standard deviation.

The obtained values of antioxidant activity examined by DPPH radical scavenging activity range from 88.48 to $2891.08 \mu \mathrm{g} / \mathrm{ml}$. The largest capacity to neutralized DPPH radicals is measured in methanol extract from stems, wich neutralized $50 \%$ of free radicals at concentrations of $88.48 \mu \mathrm{g} / \mathrm{ml}$, folowed by acetone extract from stems $(95.76 \mu \mathrm{g} / \mathrm{ml})$. On the basis of the obtained values, it is determined that examined plant parts of species E. cyparissias differ in amounts of total phenolic compounds, as well as in the quantity of flavonoids, which is one of the most significant groups of metabolites within the classification of phenolic compound, the quantity of which is put special emphasis on in this study. Apart from the qualitative differences, there are also observed differences in the degree of antioxidant activity of analysed extracts.

When comparing the values of the total phenolic compounds concentration and the values of the antioxidant activity, it is inferred that the extracts having the greatest amount of the total phenolic compounds also have the greatest antioxidant activity. This fact indicates that the secondary metabolites from the group of phenolic compounds are the main active substances with shown antioxidant activity within this population. According to Pilluza and Bullita the dependency between the antioxidant activity of extracts and the quantity of the total phenolic compounds is confirmed during the numerous analyses of biological activity of plant extracts (PIluzZA and BullitTA, 2011). However, comparison between the values of the quantity of flavonoids and the values of the antioxidant activity showed no connection between the quantity and the activity. The absence of the afore mentioned correlation implies that it is not the quantity of secondary metabolites within the group of flavonoids the only important element that should be considered, but also their chemical structure. 
According to the previous analyses of secondary metabolites found in E. cyparissias, glycoside derivates, quercetin-3-glucuronide and camphorol-3-glucuronide are determined to be the main compounds from the group of flavonoids, whereas gallic acid has been proved as the main derivate from the group of phenolic acids (STADTMANN and POHL, 1966; PAPP and SZABÓ, 2002). For these secondary metabolites in a number of studies, significant antioxidant activity has been demonstrated (PEKKARINEN et al., 1999; MERKL et al., 2010; KALITA et al., 2012). These facts indicate that the secondary metabolites from the group of phenolic compounds, constitute the main components that contribute to the antioxidant activity of $E$. cyparissias extracts.

Highest concentration of phenolic compound is found in acetone extracts. The difference in the quantity of phenolic compounds originate from the different degree of solvent polarity used for the extraction. Comparative analysis of the amount of the total phenolic compounds in the extracts indicates that the plant organs differ significantly in the amount of the total phenolic compounds, and that the ratio of the amounts of total phenolics and flavonoids in different plant parts is not the same when applying different solvents to analysis of all tested species. The difference in the amount of total phenolic compounds among plant parts is the result of different morphology, anatomy and functions of plant organs. Moreover, various amounts of total phenolic compounds is consistent with their role in the plant itself, such as a role in the protection from numerous negative effects from the environment. Differences in quantitative and qualitative characteristics are the direct consequence both of their uneven distribution and of accumulation in plant tissues.

\section{CONCLUSIONS}

In this study, the basic profile of the phenolic compounds and the biological activity by measuring the antioxidant capacity of E. cyparissias were determined for the first time. All parameters were determined for methanolic, acetone and ethyl acetate extracts from different plant parts (leaves, flowers and stems). Examined plant parts have different amounts and activity of secondary metabolites. The comparison of the effectiveness of various solvents showed large variability. Among the used, acetone had the highest extraction efficiency for plant material of $E$. cyparissias. The acetone extracts from stems contain the greatest concentrations of phenolic compounds, and showed high antioxidant activity, while the highest amount of flavonoids is found in the leaves, but they are not the main carriers of the antioxidant activity. The comparative analysis indicates that the amount of phenolic compounds and their activity depend on the plant parts and the solvents used for extraction. The obtained results imply that the secondary metabolites of E. cyparissias, besides already attested biological and therapeutic effects, have antioxidant activity which is influenced by their quantity, the manner of extraction, and as afore mentioned, by the choice of plant part and the adequate solvent. Vital to mention is the possible link between the quantity as well as the antioxidant activity of secondary metabolites measured in our experiment and antimicrobial and anticancer activity of $E$. cyparissias extracts determined so far. Application process of E. cyparissias, should be based on the fact that in addition to therapeutic, this plant contains some toxic substances which in high doses or in the wrong way of application can cause side effects. Due to this reason and in accordance with the previous results and principles in practical applications, concept of use of the E. cyparissias must be rigidly controlled and planned.

\section{Acknowledgements}

This investigation was supported by project „Promotion and popularization of active nature protection in central Serbia" and grant III41010 of Ministry of Science and Technological 
Development of the Republic of Serbia. The authors acknowledge to Ana Vučićević for manuscript lecturing.

\section{References:}

[1] Aslantürk, S.O., ÇElik-AşKin, T. (2013): Antioxidant, cytotoxic and apoptotic activities of extracts from medicinal plant Euphorbia platyphyllos L. J. Med. Plants Res. 7 (19): 1293-1304.

[2] Ayatollahi, A.S., Shojait, A., Kobarfard, F., Nori, M., Fathi, M., Choudhari, I.M. (2009): Terpens from aerial parts of Euphorbia splendida. J. Med. Plants Res. 3 (9): 660-665.

[3] Barla, A., Birman, H., Kültür, Ş., ÖKsüz, S. (2006): Secondary metabolites from Euphorbia helioscopia and their vasodepressor activity. Turk. J. Chem., 30: 325-332.

[4] BERnHOFT, A. (2010): Bioactive compounds in plants - benefits and risks for man and animals. Novus forlag, Oslo: 1-255.

[5] Botha, C.J., Penrith, M.L. (2008): Poisonous plants of veterinary and human importance in southern Africa. J. Ethnopharmacol. 119: 549-558.

[6] Brand-Williams, W., Cuvelier, E.M., Brest, C. (1995): Use of a free radicals method to evaluate antioxidant activity. Food Sci. Tech. 28: 25-30.

[7] Cristina, R.T., Chiurciu, V., Muselin, F., Dumitrescu, E. (2013): Pharmaceutical analysis of Euphorbia cyparissias included on Beta-cyclodextrin complexes. Afr. J. Pharm. and Pharmacol. 7 (26): 1814-1824.

[8] Cristina, R.T., Cosoroabă, J., Trif, A., PÂrvu, D., Hădărugă, N., Dumitrescu, E., Argherie, D., Costescu, C. (2008): Investigation on Cypress spurge (Euphorbia cyparissias L.) and its activity in the veterinery therapeutics. Bull. UASVM, Vet. Med. 65 (1): 358-363.

[9] Cristina, R.T., Dumitrescu, E., Brezovan, D., Muselin, F., Chiurciu, V. (2014): Effect of Euphorbia cyparissias ointments on acanthosis. Afr. J. Trad. Complement. Altern. Med. 11 (3): 1-6.

[10] Hsueh, F.K., LiN, Y,P., LeE, M,S., Hsieh, F.C. (2004): Ocular injuries from plant sap of genera Euphorbia and Dieffenbachia. J. Chin. Med. Assoc. 67: 93-98.

[11] Kalita, D., Kar, R., HandiQue, G.J. (2012): A theoretical study on the antioxidant property of gallic acid and its derivatives. J. Chem. Theory Comput. 11 (2): 391-402.

[12] Karimi, I., Yousefi, J., GhashghaI, A. (2010): Ocular toxicity caused by Euphorbia sap: A case report. Iran. J. Pharma. Therapeutics 9: 37-39.

[13] Kirba Ğ, S., ERecevit, P., Zengin, F., Guvenc, N.A. (2013): Antimicrobial activities of some Euphorbia species. Afr. J. Tradit. Complement. Altern. Med. 10 (5).

[14] Kumarasamy, Y., Byres, M., Cox, P.J., Jasapars, M., Nahar, L. And Sarker, S.D. (2007): Screening seeds of some Scottish plants for free-radical scavenging activity. Phytother. Res. 21: 615-621.

[15] Lantovololona, E.R., Mouafo Talontsi, F., Randriambola, L., LAATSCH, H. (2013): Radical-scavenging activity, cytotoxicity and chemical constituents of Euphorbia orthoclada from Madagascar. The Natur. Prod. J. 3 (1): 77-80.

[16] McGaw, L.J., Eloff, J.N. (2005): Screening of 16 poisonous plants for antibacterial, antihelmintic and cytotoxic activity in vitro. South Afr. J. of Bot. 71: 302-306.

[17] Merkl, R., Hradkova, I., Filip, V., Šmidrkal, J. (2010): Antimicrobial and antioxidant properties of phenolic acids alkylesters. Czech. J. Food Sci. 28 (4): 275-279.

[18] Mwine, T.J., VAn Damme, P. (2011): Why do Euphorbiaceae tick as medicinal plants? A review of Euphorbiaceae family and its medicinal features. J. Med. Plants Res. 5 (5): 652662. 
[19] Özbilgin, S., ÇıtoĞLU, S.G. (2012): Uses of some Euphorbia species in traditional medicine in Turkey and their biological activities. Turk. J. Pharm. Sci. 9 (2): 241-256.

[20] PAPP, N., SzABÓ. L.G. (2002): Some phytochemical and morphophysiological characteristics of Euphorbia cyparissias L. populations. Acta Biol. Szeged. 46 (3-4): 251252.

[21] PeKkarinen, S.S., Heinonen, I.M., Hopia, A.I. (1999): Flavonoids quercetin, myricetin, kaemferol and (+)-catechin as antioxidants in methyl linleate. J. Sci. Food Agr. 79 (4): 499-506.

[22] Piluzza, G., BullitTa, S. (2011): Correlations between phenolic content and antioxidant properties in twenty-four plant species of traditional ethnoveterinary use in the Mediterranean area. Pharm. Biol. 49 (3): 240-247.

[23] Qaisar, M., Gilani, N.S., Faroog, S. Rauf, A., Naz, R., Shaista.,Perveez, S. (2012): Preliminary comparative phytochemical screening of Euphorbia species. American-Eurasian J. Agric. Environ. Sci. 12 (8): 1056-1060.

[24] Quettier, D.C., Gressier, B., Vasseur, J., Dine, T., Brunet, C., Luyckx, M.C., CAyin, J.C., BAIlleul, F., Trotin F. (2000): Phenolic compounds and antioxidant activities of buckwheat (Fagopyrum esculentum Moench) hulls and flour. $J$. Ethnopharmacol. 72: 35-42.

[25] RanĐelović, V., Mitrović, T., JušKoviĆ, M. (2002): Farmakodinamska analiza lekovitih biljka Vlasinske visoravni. $7^{\text {th }}$ symposium on flora of southeastern Serbia and neighbouring regions, Dimitrovgrad: 111-116.

[26] Sadeghi-Aliabadi, H., Sajuadi, E.S., Khodamoradi, M. (2009): Cytotoxicity of Euphorbia macroclada on MDA-MB-468 breast cancer cell line. Iran. J. Pharm. Res. 5 (2): 103-108.

[27] Salmasi, Z., Rameyani, M., Noghabi, S.Z., Behravan, J. (2011): Euphorbia microsciadia percolation and soxhlet extracts exhibit antiviral activity. Pharmacologyonline 1: 910-920.

[28] Semnani, S.N., Rahnema, M., Alizadeh, H., Ghasempour, H. (2013): Evaluation of antimicrobial effects of Euphorbia cyparissias extracts on intramacrophages Salmonella typhi. J. of Biol. Act. Prod. from Nat. 3 (1): 64-71.

[29] Singleton, V.L., Orthofer, R., Lamuela-Raventos R.M. (1999): Analysis of total phenols and other oxidation substrates and antioxidants by means of Folin Ciocalteu reagent. Methots Enzymol. 299: 152-178.

[30] Stadtmann, H., Pohl, R. (1966): Quercetin-3-glucuronide and camphorol-3glucuronide, main flavonoids in Euphorbia cyparissias L. Naturwissenschaften 53 (14): 362.

[31] Tekao, T., Watanabe N., Yagi I., Sakata K. (1994): A simple screening method for antioxidant and isolation of several antioxidants produced by marine bacteria from fish and shellfish. Biosci. Biotechnol. Biochem. 58: 1780-1783.

[32] Thakur, A.H., Patil, A.D. (2011): Taxonomic and phylogenetic assessment of the Euphorbiaceae: A review. J. Exp. Sci. 2 (3): 37-46.

[33] Upadhyay, B., Singh, P.K., Kumar, A. (2010): Ethno-medicinal, phytochemical and antimicrobial studies of Euphorbia tirucalli L. J. Phytol. 2 (4): 65-77.

[34] Vukosavljević, P., Novaković, M., Bukvić, B., Niksić, M., Stanisavluević, I., Klaus, A. (2009): Antioxidant activities of herbs, fruit and medicinal mushroom Ganoderma lucidum extracts produced by microfiltration process. J. of Agri. Sci. 54 (1): 44-61.

[35] Wu, C.Q., Tang, P.Y., Ding, W.A., You, Q.F., Zhang, L., Duan, A.J. (2009): ${ }^{13}$ CNMR data of three important diterpens isolated from Euphorbia species. Molecules 14: 4454-4475. 